of Transumbilical Laparoscopically Assisted Appendectomy to Conventional Laparoscopic Appendectomy in Children: Surgical Laparoscopy, Endoscopy \& Percutaneous Techniques. 26(6):508-512.

6. Pisanu A, Porceddu G, Reccia I, Saba A, Uccheddu A (2013). Meta-analysis of studies comparing single-incision laparoscopic appendectomy and conventional multiport laparoscopic appendectomy. Journal of Surgical Research. 183(2):e49-e59.

7. Sara Hernandez-Martin, Lidia Ayuso, Ada
Yessenia Molina, Pison J, Miguel Angel Martinez-Bermejo, Alberto Perez-Martine (2017). Transumbilical laparoscopic-assisted appendectomy in children: is it worth it? Surg Endosc. 31(12):5372-5380.

8. Yasumitsu Hirano, Yasuhiro Ishiyama, Mari Shimada, Chikashi Hiranuma, Yasuo Hashizume, Keizo Taniguchi (2018). Comparison of Outcomes of Single-Incision Laparoscopic and Open Appendectomy in Management of Uncomplicated and Complicated Appendicitis. Indian J Surg;80(5):442-446.

\title{
ĐĂC ĐIỂM HÌNH ẢNH NộI SOI PHẾ QUẢN VÀ NGUYÊN NHÂN GÂY VIÊM PHỔI BÊNH VIỆN CỦA BỆNH NHÂN THỞ MÁY ĐIỀU TRI TẠI KHOA HỒI SỨC TÍCH CỰC - BÊ̂NH VIỆN HỮU NGHI!
}

\section{TÓM TẮT}

Mục tiêu: Mô tả đặc điểm hình ảnh nội soi phế quản về tổn thương niểm mac và lượng dich tiết của bệnh nhân Viêm phổi bệnh viện có thở máy tại khoa HSTC - CĐ bênh viện Hữu Nghị.Đặc điểm Vi khuẩn gây Viêm phổi bệnh viện (VPBV) và tình trạng đề kháng với các kháng sinh thường dùng của các vi khuẩn phân lập được. Phương pháp nghiên cứu: Nghiên cứu mố tả cắt ngang 39 bênh nhân thở máy tại khoa Hồi sức tích cực và chống độc bệnh viện Hữu Nighi từ 2/2019 đến 10/2020, được chẩn đoán Viêm phổi bệnh viện, có chỉ định Nội soi phế quản, nuôi cấy dịch phế quản cho kết quả dương tính và được làm kháng sinh đồ. Kết quả: Tổng số 39 bệnh nhân thở máy đủ tiêu chuẩn chẩn đoán VPBV, hình ảnh nội soi phế quản cho thấy đặc điểm tổn thương niêm mạc dang thâm nhiếm có tỷ lệ cao nhất chiếm 48,2\%, dịch tiết đờm loãng và đờm đặc có tỷ lệ tương đương, cùng là $38 \%$, còn lại là hình ảnh viêm mủ phế quản. Kết quả nuối cấy dich phế quản và kháng sinh đồ cho thấy nguyên nhân chủ yếu là vi khuẩn Gram âm chiếm $97 \%$, trong đó cao nhiều nhất là Klebsiella pneumoniae chiếm tỷ lệ cao nhất với $41 \%$, tiếp đó là Pseu. Aeruginosa với tỷ lê $36 \%$. Gram dương là vi khuẩn cơ hội chiếm $3 \%$, không thấy Tụ câu vàng. Acinetobacter. Baumannii chiếm tỷ lê thấp hơn tuy nhiên đề kháng kháng sinh mạnh hớn. Trong các Vi khuẩn Gram âm thường găp, tỷ lệ đề kháng rất cao với kháng sinh nhóm Cefalosphorin và Quinolon (> $70 \%)$, để kháng thấp hơn với nhóm Carbapenem, Piperacillin/Tazobactam và Cefoperazone/Sulbactam. Kết luân: Tổn thương niêm mạc phế quản và tính chất dịch tiết không có đô tương quan, tuy nhiên phân nào phản ánh mức độ tổn thương phổi, giúp thay đổi

*Bênh viện Hữu Nghị

Chịu trách nhiệm chính: Lê Quang Phương

Email: drphuongle.icu@gmail.com

Ngày nhận bài: 15.10 .2020

Ngày phản biên khoa hoc: 30.11 .2020

Ngày duyệt bài: 7.12.2020
Lê Quang Phương*, Nguyễn Minh Lực*

thái độ điều trị. Nguyên nhân gây VPBV chủ yếu là vi khuẩn Gram Âm. Các VK Gram Âm thường gặp đề kháng cao với nhiều loại kháng sinh hay dùng, đặc biệt là nguyên nhóm Quinolon và Cefalosphorin, còn nhạy cảm với Carbapenem, Piperacillin/Tazobactam và Cefoperazone/Sulbactam

Tư khóa: Nội soi phế quản, Viêm phổi bệnh viện (VPBV), Vi khuẩn Gram âm, Vi khuẩn Gram dương.

\section{SUMMARY \\ CHARACTERISTIC OF BRONCHOSCOPY IMAGES AND MICROBIOLOGICAL CAUSES OF HOSPITAL ACQUIRED PNEUMONIA IN ICU DEPARTMENT FRIENDSHIP HOSPITAL}

Objectives: Describe the characteristics of bronchoscopy images of mucosal lesions and bronchial secretions of patients with Hospital AcquiredPneumonia (HAP) with ventilatior at the ICU Department - Huu Nghi Hospital. Characteristics Bacteria cause HAP and Status resistance to commonly used antibiotics of isolated bacteria. Methods: A cross-sectional studyof 39 ventilated patients at Huu Nghi hospital's ICU department, diagnosed HAP, with indications Bronchoscopy, bronchial fluid culture showed positive results and made Antibiotic Resistance. Result: A total of 39 ventilated patients qualified for diagnosis HAP, bronchoscopy images showed the characteristics of infiltrated mucosal lesions with the highest rate accounting for $48.2 \%$, dilute sputum secretions and thick sputum, equivalent rates, the same $38 \%$, the rest is bronchitis purulent inflammation. The results of bronchial fluids and antibiotic culture showed that the main cause was Gram-negative bacteria, accounting for $97 \%$, of which the highest rate was Klebsiella pneumoniae with $41 \%$, followed by Pseu. Aeruginosa ratio $36 \%$. Gram-positive bacteria accounted for 3\%, was opportunistic bacteria. Staphylococcus aureus was not found.Acinetobacter. Baumannii accounts for a lower proportion but more resistant to antibiotics. In common Gram-negative bacteria, the rate of 
resistance is very high to antibiotics of Cefalosphorin and Quinolone groups (> 70\%), and lower resistance to Carbapenem, Piperacillin/Tazobactam and Cefoperazone/Sulbactam. Conclusion: Bronchial mucosal lesions and exudate properties are not correlated, but partly reflect the extent of lung damage, helping to change treatment attitude. The cause of HAP is mainly Gram-negative bacteria. Gramnegative bacteria are often highly resistant to many commonly used antibiotics, especially Quinolone and Cefalosphorin, and sensitive to Carbapenem, Piperacillin/Tazobactam and Cefoperazone/ Sulbactam

Keyword: Bronchoscopy, Hospital - acquired pneumonia (HAP), Gram-negative bacteria, Grampositive bacteria

\section{I. ĐẶT VẤN ĐỀ}

Viêm phổi bệnh viện (VPBV) là một trong những nguyên nhân gầy tî lệ tử vong cao (trên $30 \%$ ). VPBV là biến chứng nhiễm khuẩn nặng, tác động xấu đến kết quả điều trị, gia tăng dòng vi khuẩn (VK) đề kháng kháng sinh (KS). VPBV đặc biệt là viêm phổi có liên quan đến thở máy là biến chứng thường gặp ở các bệnh nhân tại khoa điều trị tích cực, làm kéo dài thời gian nằm viện cũng như làm tăng nguy cơ tử vong trên các bệnh nhân nặng.

Chẩn đoán VPBV còn gặp nhiều khó khăn do chưa có tiêu chuẩn vàng. Nội soi phế quản là 1 trong những biện pháp giúp lấy bệnh phẩm tại sâu trong phế quản, đảm bảo vô trùng, hạn chế vi khuẩn vãng lai xâm nhập bệnh phẩm ${ }^{(1,2)}$, kết hợp nuôi cấy trong môi trường thích hợp giúp đưa ra chẩn đoán chính xác.

Nhiều nghiên cứu mới đây cho thấy vi khuẩn VPBV đã gia tăng đề kháng với nhiều loại kháng sinh manh phổ rộng $(4,5,7)$. Tại Việt Nam, tình hình vi khuẩn VPBV cũ̃ng rất trầm trọng với các chủng đa kháng kháng sinh gia tăng khiến việc điều trị rất khó khăn và gia tăng tî lệ bệnh nhân tử vong ${ }^{(4)}$. Do vậy, việc hiểu biết đặc điểm và tình hình đề kháng kháng sinh vi khuẩn VPBV là rất quan trọng nhằm bảo đảm điều trị kháng sinh trúng đích và cải thiện tử vong bệnh nhân.

Nhằm nâng cao khả năng điều trị thành công VPBV, mục đích của nghiên cứu này nhằm mô tả đặc điểm hình ảnh Nội soi phế quản, đánh giá mức độ tổn thương niêm mạc và đặc điểm dịch tiết phế quản, từ đó thay đôi thái độ điều trị cũng như mô tả đặc điểm nguyên nhân vi khuẩn từ đó lựa chọn kháng sinh thích hợp theo khuyến cáo của các hiệp hội cũng như tình hình dịch tễ tại cơ sở.

\section{II. ĐỐl TƯỢNG VÀ PHƯƠNG PHÁP NGHIÊN CỨU}

Đối tượng nghiên cứu. Nghiên cứu trên 39 bệnh nhân thở máy tại khoa HSTC - CĐ bệnh viện Hữu Nghị từ 2/2019 đến 10/2020, chẩn đoán VPBV, có chỉ định nội soi phế quản, nuôi cấy dịch phế quản cho kết quả dương tính, được làm kháng sinh đồ

Chúng tôi loại khỏi nghiên cứu những trường hợp bệnh nhân được nội soi phế quản vì nguyên nhân khác như dị vật, chảy máu,...; kết quả nuôi cấy dịch phế quản âm tính.

Phương tiện. Máy nội soi phế quản ống mềm đường kính ống soi $5.0 \mathrm{~mm}$ của hãng PENTAX

Quy trình và dụng cụ lấy bệnh phẩm đảm bảo vô trùng

Hệ thống nuôi cấy tại khoa Vi sinh bệnh viện Hữu Nghị

Phương pháp nghiên cứu. Mô tả cắt ngang trên cơ sở thống kê số liệu thu thập được

Thu thập và xử lý số liệu. Phần mềm SPSS 20.0

Thu thập số liệu: Họ và tên, tuổi, giới, hình ảnh niêm mạc phế quản, tính chất đờm, dịch tiết phế quản có lưu lại hình ảnh trên máy nội soi phế quản; Kết quả nuôi cấy vi khuẩn và kháng sinh đồ.

\section{KẾT QUẢ NGHIÊN CỨU}

1. Tuổi: Độ tuổi trung bình $83.5 \pm 7$ tuổi, trẻ nhất là 63 tuổi, cao tuổi nhất lầ 97 tuổi phù hợp với đặc thù bệnh nhân tại bệnh viện Hữu Nghị

2. Giới: Nam $89.7 \%$, Nữ $10.3 \%$. Khác biệt không có ý nghĩa thống kê

\section{3. Đặc điểm hình ảnh nội soi phế quản}

\subsection{Tổn thương niêm mạc}

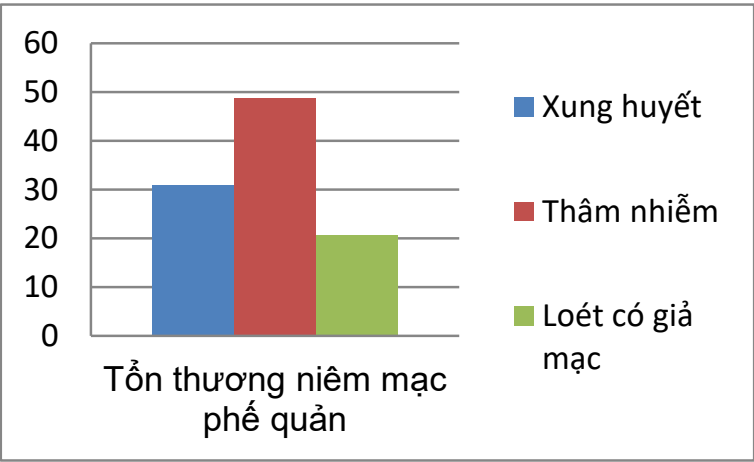

Biểu đồ 1: Tỷ lệ tổn thương niêm mạc phế quản

Nhận xét: Tổn thương dạng thâm nhiễm chiếm tỷ lệ cao nhất $48.7 \%$, Loét có giả mạc $20.5 \%$

Tổn thương mức độ trung bình bao gồm niêm mạc xung huyết và niểm mạc thâm nhiểm là chủ yếu, lần lượt là $48.7 \%$ và $30.8 \%$, Ít trường hợp tổn thương niêm mạc nặng dạng loét (20.5\%)

\subsection{Tính chất dịch tiết}




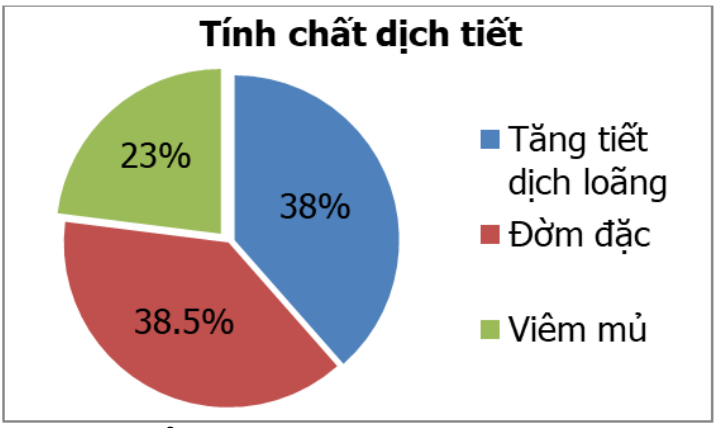

Biểu đồ 2: Tính chất dịch tiết
Nhận xét: Tính chất dịch tiết bao gồm tăng tiết đờm loãng, nhiều đờm đặc có tỷ lệ tương đồng $38.5 \%$, viêm mủ phễ quản ít hơn ( $23 \%)$

So sánh đặc điểm tổn thương niêm mạc phế quản và tính chất dịch tiết thấy mối tương quan không cao, tuy nhiên có thể thấy tỷ lệ tổn thương niêm mạc phế quản mức độ nặng là loét có giả mạc cùng với tính chất dịch tiết viêm mủ phế quản đều có tỷ lệ ít hơn, phần nào cho thây mức độ tổn thương càng nặng, dịch tiết càng nhiêu.

4. Đặc điểm tác nhân vi khuẩn gây viêm phổi bệnh viện

4.1. Tân suất tác nhân vi khuẩn

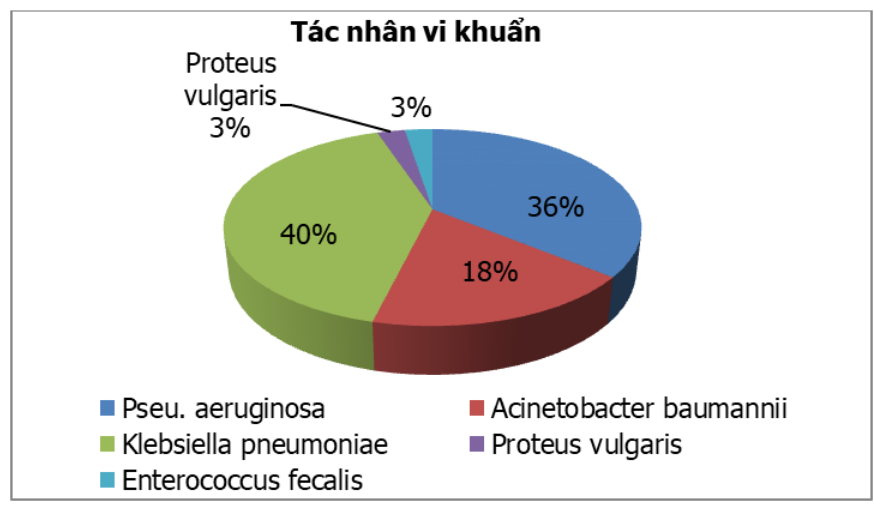

Biểu đồ 3: Tỷ lệ Vi khuẩn gây VPBV

Nhận xét: Tác nhân gây VPBV chủ yếu là VK gram âm (97\%) trong đó nhiều nhất là Klebsiella $40 \%$, tiếp đến là Trực khuẩn mủ xanh $36 \%$ và Acinetobacter Baumannii $18 \%$. Thấp nhất trong nhóm VK Gram âm là Proteus Vulgaris, vi khuẩn không điển hình. Vi khuẩn Gram dương chiếm tỷ lệ rất thấp (3\%) là Vi khuẩn cơ hội. Không thây Tụ cầu vàng trong số bệnh nhân nghiên cứu.

\subsection{Mức độ đề kháng với các kháng sinh thường dùng của Vi khuẩn hay gặp}

\subsubsection{Mức độ đề kháng kháng sinh của Pseu. Aeruginosa}

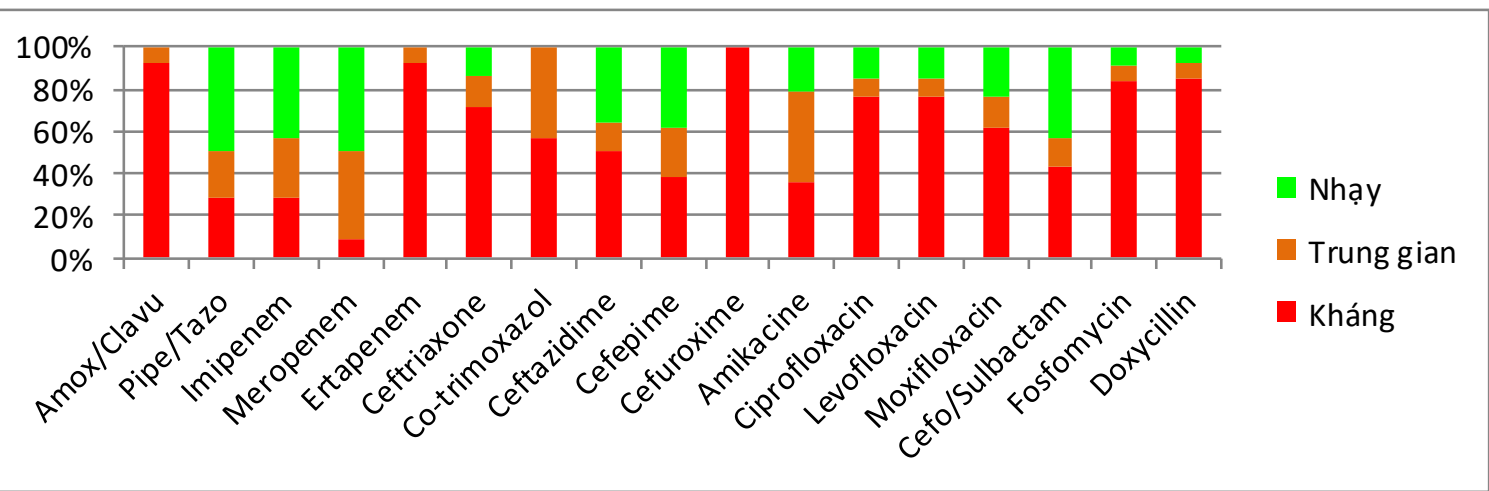

Biểu đồ 4: Tỷ lệ đề kháng KS của Pseu. Aeruginosa với các kháng sinh thường dùng

Nhận xét: Pseu. Aeruginosa đề kháng cao với nhiều loại KS thường dùng, trong đó cao cao nhất là Amoxicillin/Clavulanic Acid (92\%), Fosfomycin (82\%) và KS thuộc nhóm Quinolon (cùng $78 \%$ với cả Ciprofloxacin và Levofloxacin, $62 \%$ với Moxifloxacin); còn tương đối nhạy cảm với kháng sinh thuộc nhóm Carbapenem (42\% với Imipenem, 50\% với Meropenem), Piperacillin/Tazobactam (50\%) và Cefoperazol/Sulbactam (42\%). 


\subsubsection{Mức độ đề kháng kháng sinh của Acinetobacter baumannii}

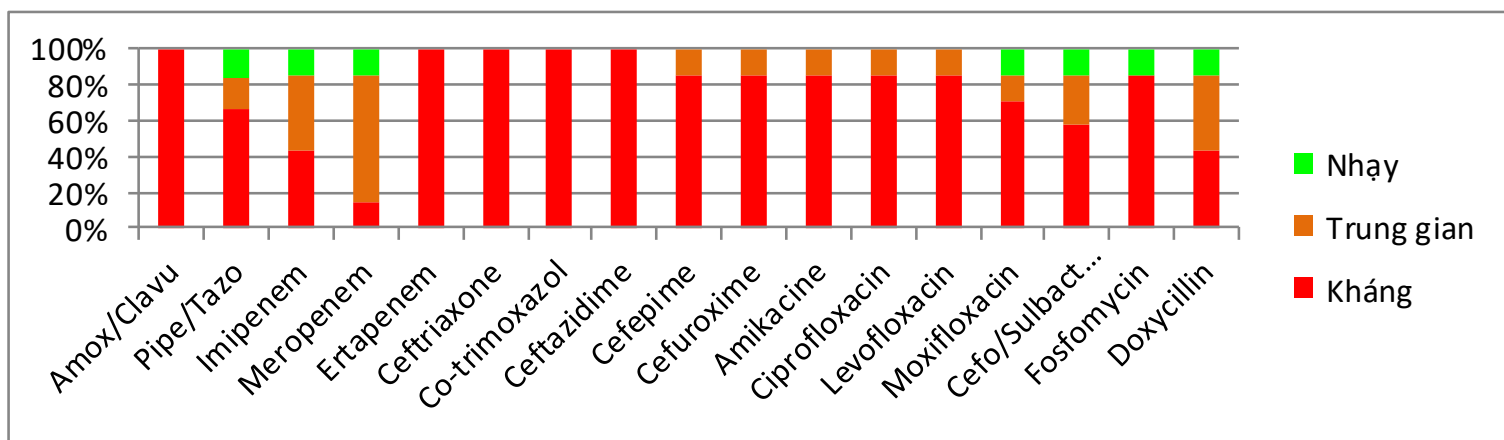

Biểu đồ 4: Tỷ lệ đề kháng KS của Acinetobacter baumannii với các kháng sinh thường dùng

Nhận xét: Mức độ đề kháng kháng sinh của Acinetobacter baumannii rất cao, kháng hoàn toàn với các kháng sinh nhóm Cefalosphorin, Quinolon $(85-100 \%)$, đề kháng cao ngay cả với kháng sinh nhóm Carbapenem, Piperacillin/Tazobactam và Cefoperazol/Sulbactam. Trong đó riêng nhóm Carbapenem có tỷ lệ trung gian tương đối cao (Imipenem 43\%, Meropenem 72\%)

\subsubsection{Mức độ đề kháng kháng sinh của Klebsiella pneumoniae}

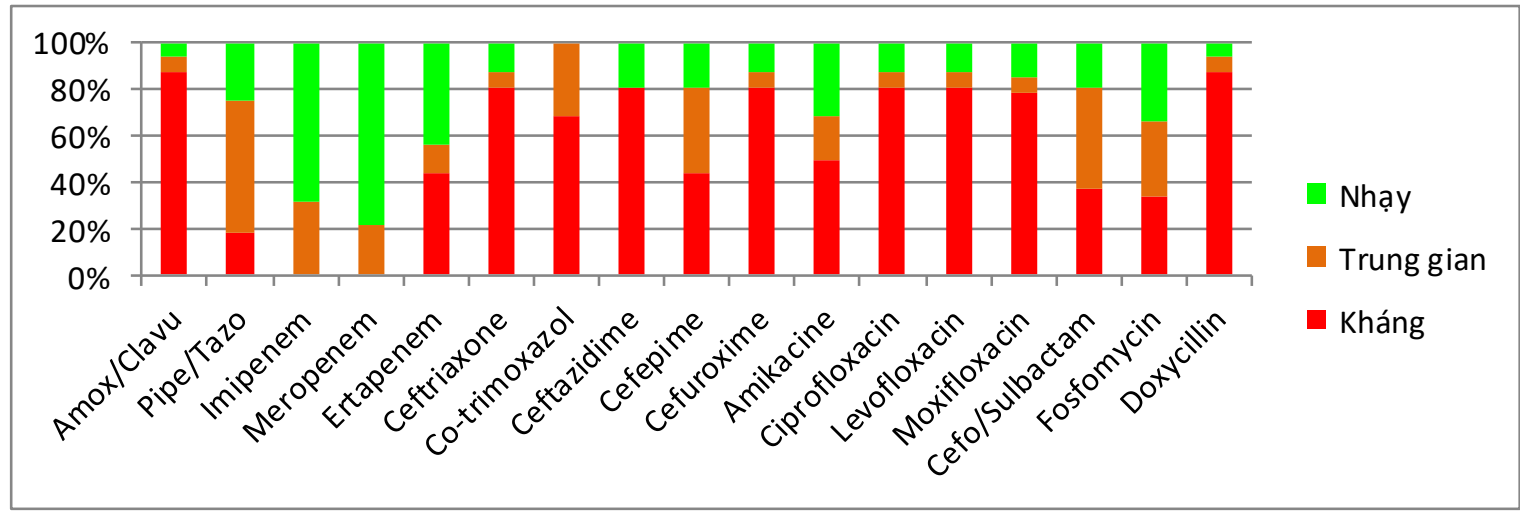

Biểu đồ 4: Tỷ lệ đề kháng KS của Klebsiella pneumoniaevới các kháng sinh thường dùng

Nhận xét: Vi khuẩn Klebsiella pneumoniae cũng có tỷ lệ kháng với kháng sinh khá tương đồng với Pseu. aeruginosa, còn nhạy cảm với kháng sinh thuộc nhóm Carbapenem, đề kháng thấp hơn với Piperacillin/Tazobactam và Cefoperazone/Sulbactam. Ngoài ra còn tương đối nhạy cảm với Fosfomycin (Kháng 32\%, nhạy cảm 32\%, còn lại là trung gian.)

\section{BÀN LUẬN}

Trong số 39 trường hợp bệnh nhân thở máy tại khoa Hồi sức tích cực và chống độc - bệnh viện Hữu Nghị, được chỉ định nội soi phế quản, lấy bệnh phẩm dịch phế quản nuôi cấy cho kết quả dương tính, chúng tôi nhận thấy hình ảnh tổn thương niêm mạc và tính chất dịch tiết không có mối tương quan rõ ràng tuy nhiên phần nào phản ánh được mức độ tổn thương phổi(1,2), trong đó hình ảnh niêm mạc xung huyết, thâm nhiễm cùng với tính chất nhiều xuất tiết loãng, đặc chiếm tỉ lệ cao, tổn thương niêm mạc dạng loét cùng viêm mủ phế quản có tỷ lệ thấp hơn.

Kết quả nuôi cấy dịch phế quản và kháng sinh đồ cho thấy, nguyên nhân chủ yễu gây Viêm phổi bệnh viện là vi khuẩn Gram âm 97\%, tương đồng với nhiều bài báo và nghiên cứu trong nước. Trong đó Klebsiella chiếm tỷ lệ cao nhất với $40 \%$ cao hơn tiếp đến là Pseu. Aeruginosa với 36\%. Thứ 3 là Acinetobacter baumannii chiếm tỷ lệ thấp hơn (18\%), tương đồng với nghiên cứu của Bùi Nghĩa Thịnh và cộng sự tại khoa HSTC bệnh viện Trưng Vương ${ }^{(8)}$ hay như một số nghiên cứu của các tác giả khác.

Tỷ lệ vi khuẩn Gram dương rất thấp (3\% với 1 trường hợp cấy ra Enterococcus fecalis, là vi khuẩn cơ hội. Trong nghiên cứu của chúng tôi không ghi nhận trường hợp nào cây ra Staphylococcus aureus, vi khuẩn thường gặp ở nhiều đđơn vị Hồi sức tích cực khác như Bạch Mai, Chợ Rẫy ${ }^{(4,5)}$. 
Tình trạng đề kháng kháng sinh luôn là mối quan tâm hàng đầu của các bác sĩ trong lâm sàng. Trong nghiên cứu này chúng tôi tập trung đánh giá tình trạng đề kháng kháng sinh của Vi khuẩn Gram âm thường gặp đối với các kháng sinh hay dùng trong bệnh viện. Kết quả cho thấy Acinetobacter baumannii có tỷ lệ đề kháng kháng sinh cao nhất, kháng gần như hoàn toàn các loại kháng sinh thương dùng trong bệnh viện, đề kháng mạnh ngay cả với nhóm Carbapenem (nhạy cảm $<20 \%)^{(6)}$

\section{KẾT LUẬN}

Hình ảnh tổn thương niêm mạc phế quản, tính chất dịch tiết đánh giá bằng nội soi ống mềm ở bệnh nhân thở máy phần nào phản ánh mức độ tổn thương phổi, từ đó giúp bác sĩ lâm sàng có thái độ điều trị thích hợp

Vi khuẩn gẩy Viêm phổi bệnh viện chủ yếu là Vi khuẩn Gram âm, tỷ lệ đề kháng kháng sinh cao, đặc biệt trong các nhóm Cefalosphorin và Quinolon, còn nhạy cảm hơn đối với nhóm Carbapenem và 1 số loại kháng sinh mới

Kiến nghị: Chỉ định nội soi phế quản là thủ thuật xâm nhập an toàn, giúp đánh giá mức độ tổn thương, lẩy bệnh phẩm xét nghiệm cho kết quả chính xác.

Lựa chọn kháng sinh và liều dùng phù hợp đối với bệnh nhân viêm phổi bệnh viện dựa trên dịch tễ vi khuẩn và khả năng kháng thuốc kháng sinh của vi khuẩn thường gặp tại cơ sở. Các kháng sinh có tỷ lệ đề kháng cao là Cefalosphorin, Quinolon. Xem xét khả năng dùng
Carbapenem liều cao do tỷ lệ trung gian với vi khuẩn tương đối cao.

TÀI LIẸU THAM KHẢO

1. Li S, Wu L, Zhou J, Wang $Y$, Jin F, Chen $X$, et al. Interventional therapy via flexible bronchoscopy in the management of foreign bodyrelated occlusive endobronchial granulation tissue formation in children. Pediatr Pulmonol. 2020.

2. Criner GJ, Eberhardt R, Fernandez-Bussy $S$, Gompelmann D, Maldonado F, Patel N, et al. Interventional Bronchoscopy. Am J Respir Crit Care Med. 2020;202(1):29-50.

3. Chawia R (2008). Epidemiology, etiology, and diagnosis of hospital -acquired pneumonia and ventilator-associated pneumonia in Asian countries.Am J Infect control.Vol.36, No.4.

4. Giang Thục Anh, Vũ Thế Hồng, Vũ Văn Đính (2002)," Tìm hiểu tình hình nhiễm khuẩn bệnh viện và tỷ lệ kháng kháng sinh tại khoa điều trị tích cực từ 1/2002 - 6/2002", cơng trình NCKH BV Bạch mai, tập 1, tr 209-18.

5. Đoàn Ngọc Duy, Trân Văn Ngoc (2012), " Đă̆c điểm viêm phối bệnh viện do Pseudomonas aeruginosa tại BV Chơ Rẫy từ 6/2009 đến 6/2010", Y Học TP. Hồ Chí Minh, Tập 16, Phụ bản của Số 1 ,tr 87 - 93.

6. Nguyễn Phú Hương Lan, Nguyễn Văn Vĩnh Châu, Đinh Nguyển Huy Mẫn, Lê Thị Dưng, Nguyễn Thi Thu Yến (2012) "Khảo sát mức đố đề kháng kháng sinh của Acinetobacter và Pseudomonas phân lập tại Bệnh viện bệnh nhiệt đới năm 2010 ". Thời sư Y̛ hoc, số 68, tr 9-12

7. Huỳnh Văn Ân (2012), Thực trạng sử dụng kháng sinh trong viêm phối bệnh viện tại Khoa hồi sức tích cức BV Nhân Dân Gia Đinh, Hội thảo khoa học ngày 21/4/2012, TP. HCM.

8. Bù̀i Nghĩa Thinh và công sứ (2010), Khảo sát tình hình đề kháng KS của VK tại khoa Hồi sức tích cực và Chống Độc bệnh viện Cấp cứu Trưng Vương, Hồ Chí Minh.

\title{
ĐÁNH GIÁ KẾT QUẢ ĐÎ̀̃U TRI LOÃNG XƯƠNG TRÊN BỆNH NHÂN SAU THAY KHỚP HÁNG DO GÃY XƯO'NG TAI KHOA NGOAI CHẤN THƯƠNG - CHİNH HÌNH, BỆNH VIỆN THỐNG NHẤT
}

\author{
Võ Thành Toàn*, Nguyễn Bảo Lục*, Nguyễn Văn Sỹ*
}

\section{TÓM TẮT}

Mục tiêu: Đánh giá kết quả điều trị loãng xương ở người cao tuổi sau thay khớp háng do gãy tại khoa ngoại Chấn thương Chỉnh hình. Đối tượng và phương pháp nghiên cứu: Nghiên cứu hồi cứu mô tả 175 bệnh nhân thay khớp háng tại Bệnh viện Thống

*Bệnh viện Thống Nhất

Chiu trách nhiệm chính: Võ Thành Toàn

Email: vothanhtoan1990@yahoo.com

Ngày nhận bài: 19.10.2020

Ngày phàn biện khoa học: 27.11.2020

Ngày duyệt bài: 7.12.2020
Nhất từ 01/2018 đến 12/2019. Kết quả: Trong 175 bênh nhân có $85,1 \%$ loãng xương, $84,7 \%$ bênh nhân loãng xương tuân thủ điêu trị và không gãy thêm lần nữa, 94,4\% bênh nhân bỏ điều trị loãng xương bi gãy thêm lần nữa. Kết luận: Điều trị loãng xương trên bênh nhân lớn tuổi gã̃y xương vùng háng rất cần thiết, bên cạnh đó bệnh nhân cần bám sát quá trình điều trị để giảm thiểu mức độ gãy xương thêm lần nữa.

Tư khóa: loãng xương, thay khớp háng, gãy xương vùng háng.

\section{SUMMARY}

ASSESSMENT OF TREATMENT RESULTS OF OSTEOPOROSIS PATIENTS WITH HIP 